\title{
INDEX / INDEX
}

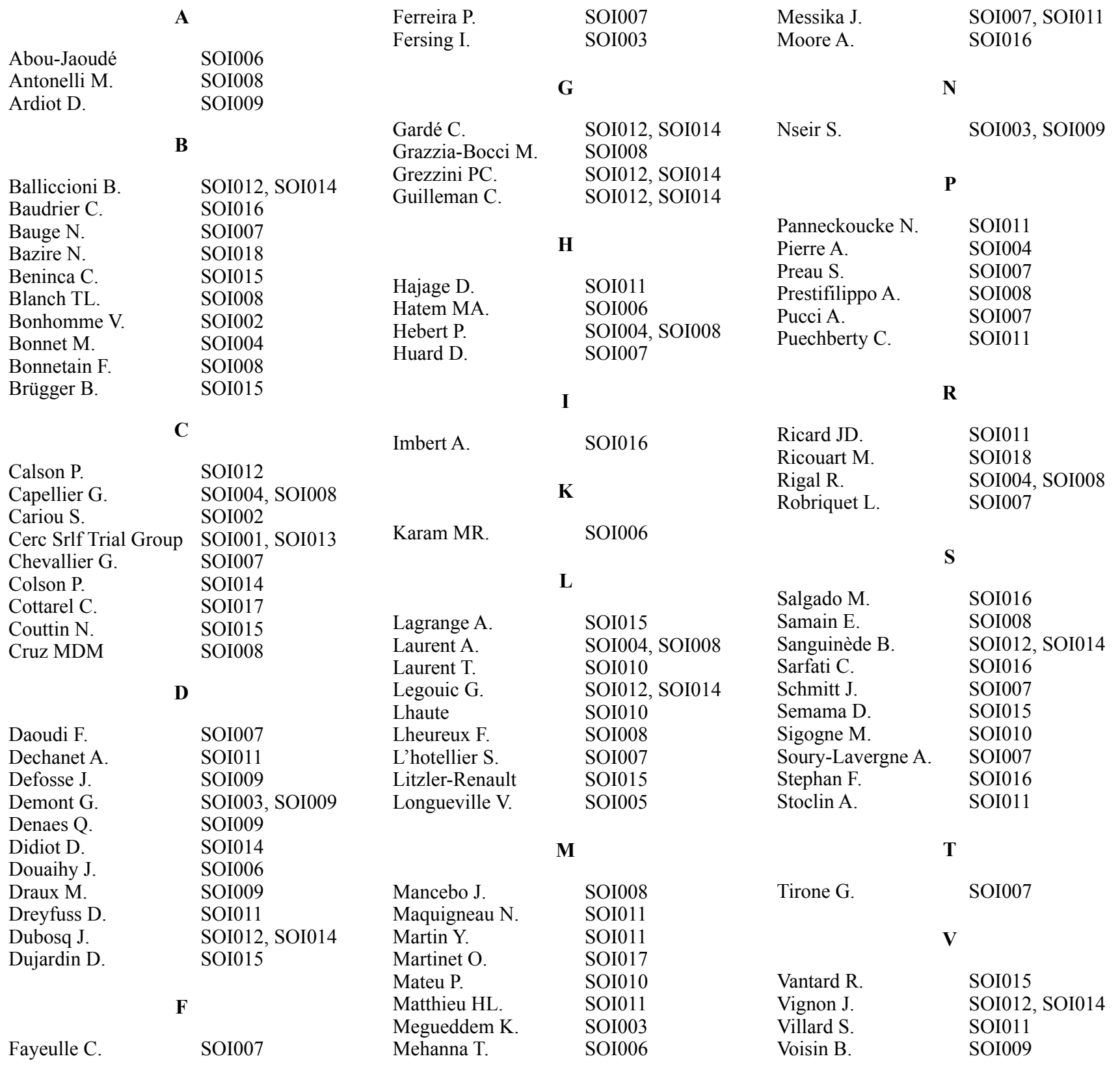

